\title{
Problems and Prospects of CSR System Development in China
}

\author{
Jie Wang \\ Zhuhai Campus, Beijing Institute of Technology \\ 6 Jin Feng Road, Tang Jia Wan, Zhuhai 519085, China \\ $\&$ \\ School of Management, Dalian Polytechnic University \\ 1 Qing Gong Yuan, Gan Jing Zi, Dalian 116034, China \\ Tel: 86-411-8632-3622 E-mail: wangjiezhao@hotmail.com \\ Sheng Qin \\ School of Management, Dalian Polytechnic University \\ 1 Qing Gong Yuan, Gan Jing Zi, Dalian 116034, China \\ Yanjuan Cui \\ School of Management, Dalian Polytechnic University \\ 1 Qing Gong Yuan, Gan Jing Zi, Dalian 116034, China \\ E-mail: tsuiyanjuan@163.com
}

The research is financed by Education Department of Liaoning Province. No. 2008071

\begin{abstract}
Corporate Social Responsibility (CSR) reporting system is the system to disclosure the institutions and organizations influence on the environment, economy and society to the public. It is a great improvement of CSR that has been issued by advanced enterprises. However the CSR development is still unbalance in China, half of them are in the initial stage. The whole level of CSR is not high and the disclosure breadth and depth are not deep to cover the stakeholder requirements and corporate value. There are lack of development in strategies and specific mechanisms of corporate implying CRS, while there are more improved spaces in the moral or voluntary implementation. In the practice of CRS, the corporate should fully consider the overall efficiencies of economy, society and environment, so that it is possible for CRS to develop sustainable. Therefore, Corporate should focus on the innovation of CSR process.
\end{abstract}

Keywords: Corporate social responsibility, CSR system, Triple bottom line

\section{The significance and necessity of constructing CSR system in China}

Corporate social responsibility (CSR) refers to the responsibilities of the enterprises in their commercial operations. CSR concept is based on the idea of the business operation being consistent with sustainable development. Corporate should consider its social and natural environment impact including their financial and operating conditions. CSR report is the corporate voluntary and public report for economic, environmental and social performance generated by their activities, products and services. That is, CSR system is the system that triple bottom line impacts of environment, economy, and society generated by institutions and organizations activities will disclosure to public. With the world economy developing to the low-carbon, recycling, sustainable direction, all nations focus on construction of sustainable development more and more. During the process of promoting sustainable development in China, corporate CSR system has been gotten more attention, especially in the recent years, it has great development with the improve of people awareness-raising the company's position and responsibilities and more understanding the significance and necessity of CSR system. In summary, the significance and necessary of constructing corporate CSR system in China can be expressed as following. 


\subsection{CSR system is objective and internal requirements of sustainable development in China}

Since reform and opening in China, the annual GDP has achieved more than $8 \%$, at the same time; we have also paid a great cost of excessive consumption in energy resources and environmental pollution etc. Enterprises, as important social economic cells, have made an important contribution to economy development; on the other hand, have inescapable responsibility for resource and environmental issues. Some companies make profit maximization as the single goal, then harm the legitimate rights and interests of workers and consumers, predatorily use resources and damage public interests, which results in the complicated contradictions of business and society, even some enterprises have closed down due to lose the trust of the people. Over the time, there will not achieve sustainable development and the harmonious society in China. So enterprises are required social responsibilities by national fundamental interests of sustainable development, and report the fulfillment of CSR to society timely, comprehensive and systematically. Then the CSR will be standardized, which is a basic protection system to achieve sustainable development and objective needs of building a harmonious society in China.

\subsection{CSR system is an important measure and effective way to win the trust}

In the globalization, from the successful experience of enterprises in the world, it is easy to see that these enterprises often not only consider the different demands of stakeholders to fulfill its relevant responsibilities better, but also report their strategic policy and its responsibility implementation timely to establish the corporate responsibility image to get the trust, understanding and support of stakeholders. In the world a considerable number of multinational companies are preparing CSR reports, some large enterprise even establish the relevant specialized agencies taking the work into their daily schedule. In the international market, there is growing emphasis on gathering the information of corporate social responsibility, and make it as an important factor to consider corporate credit and strength. It has been an essential part for Chinese business joining the world to strengthen the building of corporate CSR system. It is an important measure to get international community reorganization in the international competition and cooperation, and to build the new image of Chinese enterprises. And it is also a very effective way for enterprises to make the community understand and win the trust of people.

\subsection{CSR system is the important security and institutional foundation to safeguard the public's knowing right}

With the market economy development step by step, information resources are increasingly demonstrating an important role today. It can bring enormous economic benefits and other important powers of the people. However, the market economy rules results in asymmetric information, a lot of information should be known by stakeholders was not disclosed for enterprise interests or failed to publish for not establishing communicating bridge between enterprises and stakeholders. Much more condition is that the information is neglect to publish for not giving great attention and without public system to follow, which made the public's right to know is not protecting reasonably. The CSR system is a system standard for corporate fulfilling social responsibility of reports to the community regularly. If it can be established, it will be able to play an important role in safeguarding the right to know the enterprise fulfilling social responsibility for public.

\subsection{CSR system is the measurement to promote enterprise to accept social supervision}

As the foundation organization of social economy construction, the enterprise is a crucial element of the development of economy, environment and society. The development of society not only encourages enterprises to perusing the profit, but also requires them not to disobey the law and ethics and not harm the public benefits. CSR system is the effective measurement for national management sectors and public to know the enterprise contribution, to know the resource consumption, efficiency and the environmental loads, and to know their caring for employees and surviving the community etc, so that the enterprises can be oversight by management and public opinion and made to discipline themselves more consciously to the triple bottom lines of economy, society and environment to become a qualified corporate citizen.

\section{The development of CSR system in China}

\subsection{The initiative creation phase of Advanced Enterprise}

In the late-1990s, environmental information disclosure model had been evolved into coexisting social responsibility report and sustainable development report at the same time, and also some companies still use the environmental report. In 2000, the Global Initiative Organization (GRI) provided a global standard for preparing report by launching the Sustainability Reporting Guidelines. More and more international enterprises published voluntarily the CSR reports on a regular time. With economic globalization, China's advanced enterprise began to keep pace with the world process. ISO14000 environmental management standards are launched in December 
1996, which greatly promoted the formation of corporate CSR system. Until 1999, the mode of circular economy was tried in China, and a lot of model provinces and corporate were established. They began to make implemented programs of circular economy and enlarge the construction of managing environmental responsibility system. Those were very important for enterprise to increase social responsibility and establish CSR system. Environment report by Volkswagen Shanghai corporate in 2000 played a very important role in promoting CSR system construction. However, the first fully reflecting CSR information is the corporate environmental health and safety report 2000 published by China National Petroleum Corporation in 2001, and then in 2004 China's Baoshan Iron and Steel Co., Ltd. announced corporate environment report 2003. Those two big companied published voluntarily CSR is the brave act of social responsibility. It has played a very important model role in our country to set up the construction milestone for enterprises to establish CSR reporting in China.

\subsection{The central government-led advance}

China State Council issued China's Ten Countermeasures on Environment and Development in August 1992, which indicates that China has established a basic national policy of sustainable development and identify the direction and development measures. In 1996 the State Department of Environmental Protection (the State Environmental Protection Administration formerly) vigorously promotes the ISO14000 environmental management standards certification system, it is a strong impetus for enterprises to develop CSR reporting. In 1999, China began the trial mode of circular economy to enlarge the management of corporate environmental system construction, and promote some of the advanced companies to disclose CSR consciously to start publication of relevant reports.

In June 2003, the former State Environmental Protection Administration issued 101 documents, which required enterprise preparing and replenishing to capital market to disclose environmental responsibility information in SEPA or local Environmental Protection Bureau website for supervision and audit. That promoted the publication of corporate environmental responsibility information and CSR system has been expanded fatherly. Measures on Disclosure of Environmental Information (Trial) provide voluntary and mandatory requirements of environmental information of government and enterprises in May 1, 2008. To encourage the responsibility sense of enterprises sustainable development the state Department of Environmental Protection has established a corporate social responsibility (including environmental responsibility) report transfer center to collect and exchange local and foreign CSR (including environmental responsibility report). By far Measures on Disclosure of Environmental Information (Trial) are the most direct, comprehensive and authoritative policy basis to deepen CSR construction in China, and it has given an important overall guidance for constructing CSR system.

\subsection{Local authority demonstration guides}

Some advanced local governments, e.g. Shandong, Jiangsu and so on, and municipal governments such as Dalian, Nanjing, and Qingdao etc. In 2009 Shandong Guidelines for Corporate Environmental Report (Guide in short) issued, which is the first time in China to order the enterprise environmental information public behavior with standard. Some key enterprises are selected as experience unit to prepare the environmental reports, and then promote in the province. All the key enterprises of compulsory clean production audit are required to write the orporate environmental reports. The Guide is composed of 6 parts total 96 items, and reflects the company's information from 24 aspects. There are 50 basic indicators and 46 selected indicators in it; that the material influence and environment accountant are introduced made it distinct, reasonable and feasible. From then on, 46 enterprises announced the environmental reports. Strong repercussions were aroused among the community. Another example is in Dalian, which is the first government to guide enterprises to establish CSR system. In December 2006, Dalian Municipal Environmental Protection Bureau issued the pilot work document on the development of corporate annual environmental reports (DL UNCED (2006) 204 document), which identified six enterprises as model units who has passed ISO14000 environmental management system certification to carry out experimental work of annual environmental reports. And in order to facilitate the enterprise write corporate environmental reports, corporate environmental reporting framework was proposed for the first time. In 2007, after praising successful experience of Dalian Office Equipment Co., Ltd., Canon and other 6 enterprises, Dalian Environmental Protection Bureau issued a document (DL UNCED (2007) 238 files) to expand the environmental report model enterprises to 13 enterprises and issued the environmental report outline of 2007, which guided the enterprises to write the CSR report form triple bottom line of the socio-economic environment, and environment-oriented based on Sustainable Reporting Guidelines of GRI and the real needs of Dalian sustainable development, which help the constriction of Dalian enterprises CSR reporting as a high starting point and level. In December 2008, Dalian Municipal Environmental Protection Bureau held a meeting of "Dalian enterprise environment annual report experiment site summary and sustainable development report 
mobilization, Dalian Office Equipment Co., Ltd Canon, China North Vehicle Group Dalian Locomotive \& Rolling Stock Co., Ltd and 11 experimental units were praised. Another document was issued to promote the construction of CSR system, and 14 companies have volunteered to become a pilot unit of sustainable development report. More businesses were called to participate in this work that benefits the country. With the experiences of 3 years ago and multi-aspect discussion, Dalian Municipal Environmental Protection Bureau issued a document (DL UNCED [2009] No. 53) to rename "corporate annual environmental reports" as "enterprises Sustainable Development Report " in December 2009, in order that the system can be carried out more thorough specification.

\subsection{Requirement of supervisory departments}

In September 2006, Shenzhen security Exchange market, as one of the two interior regions stock exchange of China, issued the Shenzhen Stock Exchange Guidelines on Listed Corporate Social Responsibility to promote listed companies committing the social responsibility positively according to the laws, regulations, rules and learn from experience in international markets in order to imply the scientific concept of development, harmonious society and promoting sustainable economic and social development. There are 8 chapters and 38 items in it to encourage the listed companies to establish social accountability, periodic inspection and evaluate the problems of CSR implementation to write social responsibility report. After a claim on the Shenzhen Stock Exchange, the listed companies in the Shenzhen Stock Exchange have started to compose the company CSR reports, have caused strong repercussions in the community, receives the high praise from the shareholders and community, played a very good role.

In May 2008, the Shanghai Stock Exchange has issued "the listed corporation in Shanghai stock market environmental information disclosure direction", which put forward the index of social contributions value of a share for the first time. That is, based on company's basic earnings per share, the enterprise will increase revenue for the country during the year, wages paid to employees, payments interest on loans to banks and other creditor and created value amount for other stakeholders, deducted other social costs caused by environmental pollution to calculate the company create added value per share for the community, promote corporate disclose the value of a share of social contributions in the annual CSR. The specific content of social responsibility annual report raised at least include the following: Firstly, the work of the companies in the promotion of the social sustainable development, such as staff health and safety protection, the protection and support of the host community, product quality checks, etc.; secondly, the work of the companies in promoting environmental and ecological sustainable development, such as how to prevent and reduce pollution, how to protect water resources and energy, how to ensure the suitability of living of your area, and how to protect and enhance regional biological diversity and so on; lastly the work of the company in promoting economic sustainable development, such as how to use their products and services create value for customers, how to create better job opportunities and future development for staff, how to bring its shareholders with high economic returns and so on.

The Guidelines issued in the two stock exchanges has played a good role in guiding and monitoring for the listed companies, so that more and more Chinese enterprises disclosed CSR report, the number increased from dozen in 2005 to581 in 2009. In addition, State-owned Assets Supervision and department management committee (SASAC) in China also release <corporate social responsibility on the central guidance> in January 2008. It requires conditional corporate to release social responsibility report or sustainable development report regularly. Until now, most of 127 central enterprises in SASAC supervision have issued the CSR reports.

\subsection{Industry association promote vigorously}

In January 2005, China Iron and Steel Industry Association saw the experience of Shanghai Baoshan Steel Corporation group annual environment report as the important work, promote it to the whole industries. That is the first measurement to promote CSR by industry association. China Textile Industry Association (CTIA) is the most positively to promote the CSR construction. In March 2005, China Textile corporate social responsibility management system (CSC9000T) was issued by CTIA, and in May CTIA social responsibility promotion Committee was established, which issued CSC9000T China Textile Corporate Social Responsibility Management System for General and Conditions (2005 Edition). The related documents of CSC9000T implementation policy paper, CSC9000T performance evaluation points were issued in March 2006. CSC9000T pilot projects formally launched, the first 10 pilot enterprises confirmed in March 2006. The first China's textile and garment industry social responsibility annual meeting successfully held in December the same year, showing the first results of the implementation of business experience and published the first national annual report on industry social responsibility, which caused great concern of the international and domestic stakeholders. At the meeting, "10 +100+1000" project of CSC9000T was started; accumulation places of China 10 textile and 
garment industry became a pilot area of the project. They will help 100 key enterprises in these areas to establish the CSC9000T social responsibility management system and train social responsibility for 1,000 SMEs. At present, the construction and promotion of China textile corporate social responsibility management system CSC9000T work penetrates solidly into the related industrial colony and the enterprise. In 2007, Textile corporate social responsibility management system was included in the recommended industry standard plans. CTIA office formulated social responsibility management system in accordance with international practice, China's legal and industry specific conditions. 29 guidance documents formulated in Management system can be directly applied to the entire business management process, which aims at creating mechanisms to achieve continuous improvement make CSR system of corporate social responsibility as a complete system.

With the growing awareness of social responsibility, charged with the task of promoting corporate social responsibility system construction has become a consensus for more industry associations. In April 2008, China Industrial Economic Federation and 11 industrial trade associations of coal, machinery, steel, petrochemical, light industry, textiles, building materials, nonferrous metals, electric power and mining jointly issued China's industrial enterprises and industrial associations Social Responsibility Guide and A number of views to promote and advance the industrial enterprises and industrial associations to fulfill their social responsibility, in order to enhance the social responsibility of the industrial enterprises and industrial associations, strengthen the concept of social responsibility to guide more industrial businesses and industry to fulfill their social responsibilities. The stronger promotion gave by association has made more and more enterprises begin building CSR system.

In May 2009, China Banking Association, as a non-industrial association, firstly release China's banking sector social responsibility report. The report introduced China's banking sector fulfill their social responsibility relented circumstances from the contribution of the banking sector to economic and social development, stakeholders responsible and dedicated public charity, environmental protection support and banking social responsibility management. Its significance lies in the association's momentum and the leading role. That is not only industry but also other industries have taken responsibility to fulfill their social obligations to report the fulfillment of social responsibility to the public.

\subsection{The numerous enterprises follow up positively}

As mentioned above, since the China National Petroleum Co., Ltd. first announced the year 2000 corporate environmental health and safety report in 2001, with the encouragement of central and local government, CSR system has been developed a lot from 2001 to 2005, showing a rapid growth trend. Shown in Figure 1.

Studying from the name of corporation CSR report, most companies prefer our CSR report as a name of discoursing social responsibility information report, but from the world trend, more and more enterprises begin to adopt the report as sustainable development report. However, from the content of the report disclosed, the overwhelming majority of the enterprises from the economic, environmental and social triple bottom line disclose corporate social responsibility information, the same to the basic framework of global enterprise CSR report.

From the industry of the enterprise had disclosed CSR report inspects, the performance of the energy and electronics industry's business highlights, shows that the advanced industry of our CSR system construction has taken shape. Shown in Figure 2.

From the contents of the CSR report released inspects, as 14 companies' annual report of Dalian in 2008 example, the content of the report showed unbalance, incomplete and prevalent problem. The main reason is the basis work of the report is weaknesses further lack of status. For example, general lack of environmental accounting, rare enterprise implements the audit of the company environmental report. Corporate CSR reports of advanced countries compared to reports of Chinese enterprises both form and content still have significant gaps.

\section{The future job and effort}

\subsection{To establish enterprise CSR reporting evaluation system and the appraisal commendation system}

At present, China government agencies, regulators, trade associations issued a number of CSR system rules and norms. The normative purpose of these systems is consistent, however, those different policies made enterprises get a lot of repetitive work when writing CSR, and some companies need to report 2-3 different types of the report. Different rules and norms affect the comparability among enterprises, and cause the usefulness of the information disclosure compromised. Therefore, it is necessary to integrate the system on the different agencies to form a more scientific and meticulous norms or national standard. 


\subsection{To uniform corporate CSR system norms, enhanced it comparability and usefulness}

In order to promote the development of CSR system, implement the scientific concept of development, CSR reporting evaluation system should be establish. And different levels of evaluation systems should be also building up to appraisal commendation regularly. Encouraging the advanced is the realization the basic national policy of sustainable development to promote corporate citizenship initiative to assume social responsibilities.

3.3 To strengthen macro guidance and promote the construction basis work of corporate environmental accounting

The basis job of environmental accounting is to conduct data collection, collation, recording, and analysis on impact of resources and environment in enterprise daily operative activity and funds movement, and then according to environmental accounting principles it confirmed the different categories of environmental assets, environmental liabilities, environmental costs and environmental benefits. If it can be value with scientific way, resources environment process is recorded to improve the environmental cost-effectiveness accounting system, if not, alternative units will be used. Only those jobs are better, environmental accounting report will be authentic and with information value. However, the majority China's enterprises currently are lack of basic e environmental accounting knowledge. They needed help. So China's environmental protection department in conjunction with accounting department organizes experts and scholars should discuss environmental accounting instruction manuals and other guidance documents to help businesses to establish and perfect the basis work of environmental accounting.

\subsection{To develop enterprise CSR report verification and enhance the credibility}

One of the important objectives of corporate publishing corporate CSR reports is to establish a corporate image and get understanding and support business strategic policy from the public. it will undoubtedly enhance the credibility of the report, is beneficial to the company and more accountable to the public, if neutrality verification organization or the expert appraisal the enterprise's CSR report. Because CSR report covers three areas of society responsibility information of economy, environment and society, only one professional organizations or expert will have difficultly in appraisal work. Different experts or organizations should complete it together, Such as accounting firms and environmental experts complete, or the environmental evaluation organization and accountant expert together. Some foreign companies employ different experts to state the respective opinion with specialized standpoint, and let readers determine credibility of it, it is also good experience for reference.

\section{References}

Chen MENG. (2007). Analysis on CSR in China. China business \& trade, 7, 227-228

Geping QU. (2001). Development of circular economy is the trend of the 21st century. china environmental protection industry, 3, 6-7

Xuguan LI. (2007). Analysis on CSR. Market modernization, 29, 353-354

Ying XU \& Jie NIU. (2010). CSR evaluation index system. Co-operative economy \& science, 3, 12

Yong LU. (2009). Information content analysis and recommendations of CSR report. Finance and accounting monthly, 3,22 


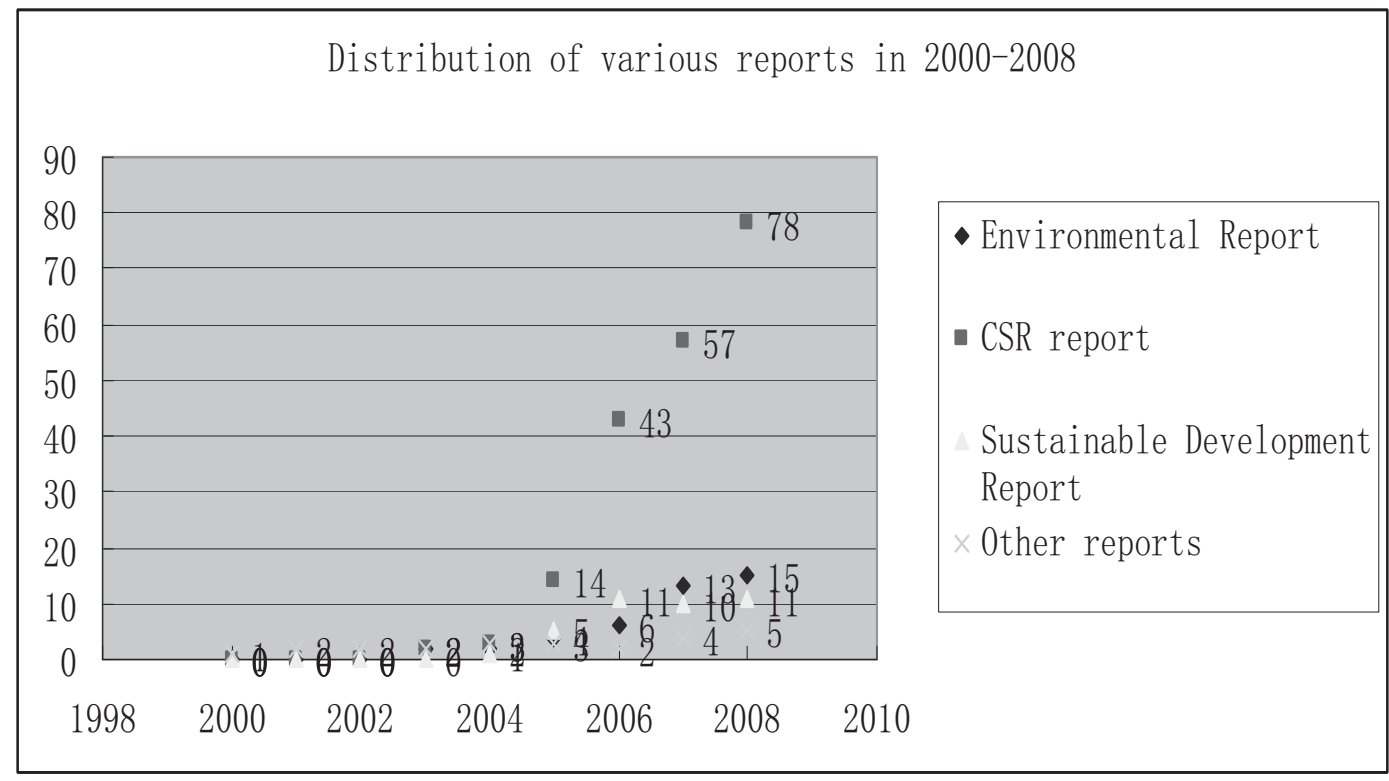

Figure 1. Different Reports Distribution in 2000-2008

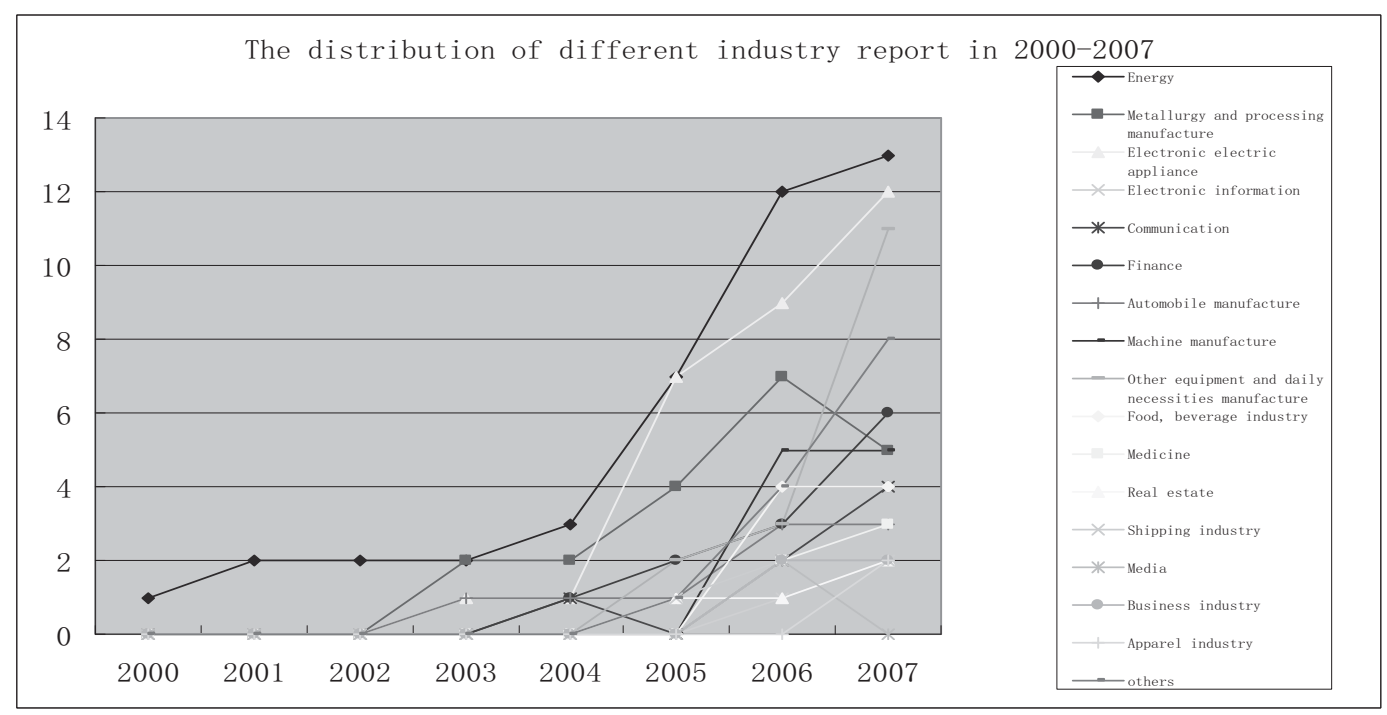

Figure 2. Distribution of Different Industry Report in 2000-2007 